Portland State University

PDXScholar

1985

\title{
A phylokaryotypic evaluation of the genus Tursiops (family Delphinidae)
}

Melissa Kay Estes

Portland State University

Follow this and additional works at: https://pdxscholar.library.pdx.edu/open_access_etds

Part of the Animal Sciences Commons, and the Biology Commons Let us know how access to this document benefits you.

\section{Recommended Citation}

Estes, Melissa Kay, "A phylokaryotypic evaluation of the genus Tursiops (family Delphinidae)" (1985). Dissertations and Theses. Paper 3440.

https://doi.org/10.15760/etd.5324

This Thesis is brought to you for free and open access. It has been accepted for inclusion in Dissertations and Theses by an authorized administrator of PDXScholar. Please contact us if we can make this document more accessible: pdxscholar@pdx.edu. 
AN ABSTRACT OF THE THESIS OF Melissa Kay Estes for the Master of Science in Biology presented May 1, 1985.

Title: A Phylokaryotypic Analysis of the Genus Tursiops (Family Delphinidae)

APPROVED BY - THE MEMBERS OF THE THESIS COMMITTEE:

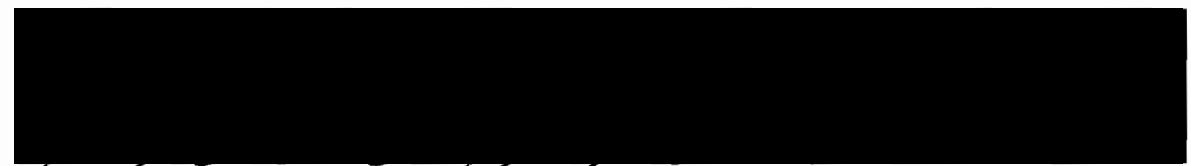

Les tex J. Newman, Ehairperson

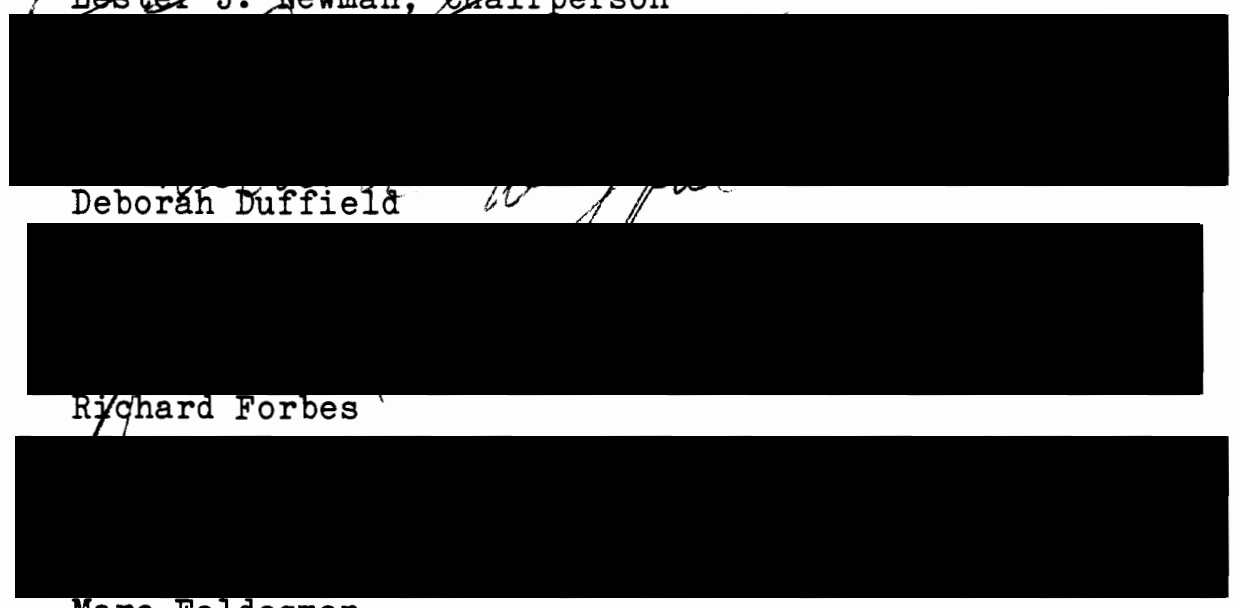

Marc Feldesman

There is considerable controversy over the number and distribution of species in the genus Tursiops (Odontoceti: Delphinidae).

In an attempt to correlate genetic data with possible species delineation, this study investigates the presence of chromosomal variants between the North Atlantic bottle nose dolphin, Tursiops truncatus, and the North Pacific bottle nose dolphin, T. gilli. Blood 
samples were obtained from oceanaria in the United States. Location of capture was correlated with karyotype to compare chromosome morphology with geographic range.

The samples of whole blood were added to culture media and incubated for four days, then treated with Colcemid to collect a number of cells undergoing mitosis. Metaphase cells were harvested and mounted on glass slides. For standard karyotyping the slides were stained with Giemsa. A C-banding technique was used to examine heterochromatin distribution by pretreatment of the slides with an alkaline solution and then staining with Giemsa.

Cells from each animal were examined by microscope and photographed. Karyotypes were constructed from the photographic prints, and chromosome morphology and banding patterns were compared.

There was considerable variation in C-banding among the Tursiops examined. There were no clear distinctions between the Atlantic and Pacific forms, nor between coastal versus offshore captive sites.

The results indicated that Tursiops populations exhibit a great deal of chromosomal polymorphism in the form of C-band heterochromatin variability. 


\title{
A PHYLOKARYOTYPIC EVALUATION OF THE GENUS TURSIOPS (FAMILY DELPHINIDAE)
}

\author{
by
}

MELISSA KAY ESTES

A thesis submitted in partial fulfillment of the requirements for the degree of

MASTER OF SCIENCE

in

BIOLOGY

Portland State University

1985 
TO THE OFFICE OF GRADUATE STUDIES AND RESEARCH:

The members of the Committee approve the thesis of Melissa Kay Estes presented June 15, 1985.

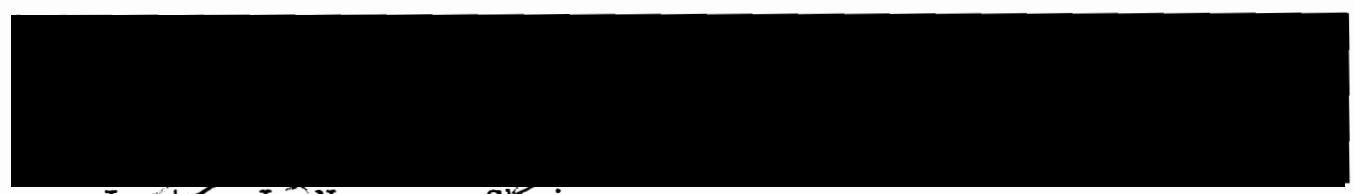

Lester $J$. Newman, Chairperson

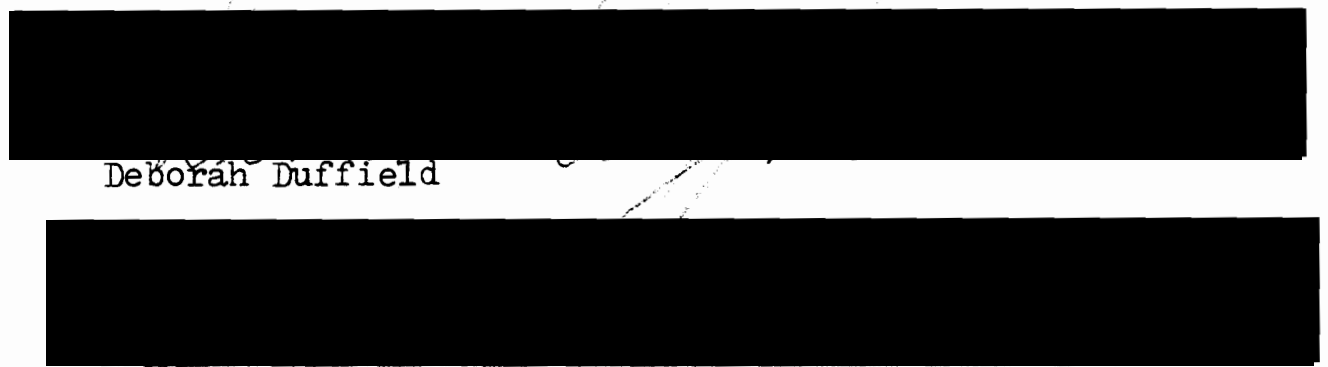

Ríchard Forbes

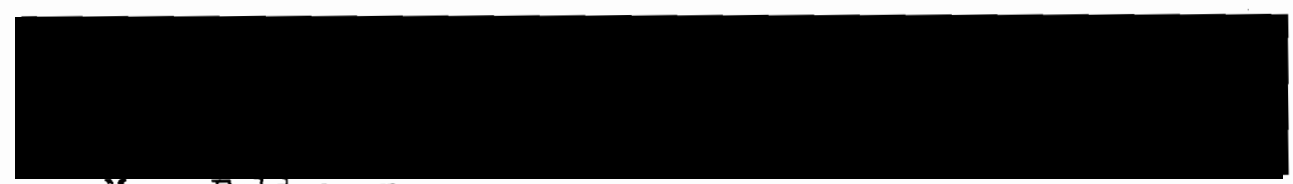

Marc Feldesman

\section{APPROVED:}

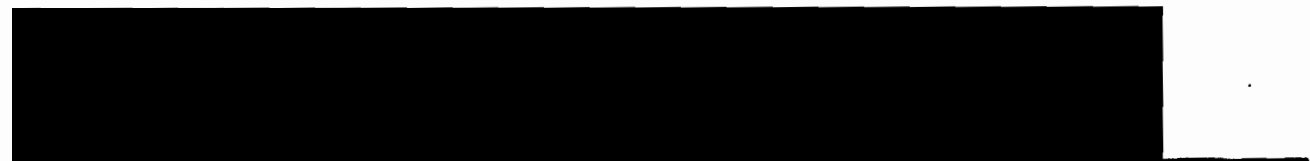

W.H. Taylor, Head, Department of Biology 
TABLE OF CONTENTS

PAGE

LIST OF TABLES.............................. iv

LIST OF FIGURES $\ldots \ldots \ldots \ldots \ldots \ldots \ldots \ldots \ldots \ldots \ldots \ldots \ldots \ldots \ldots \ldots \ldots \ldots \ldots$

CHAPTER

I. INTRODUCTION...........................

II. LITERATURE REVIEN........................ 4

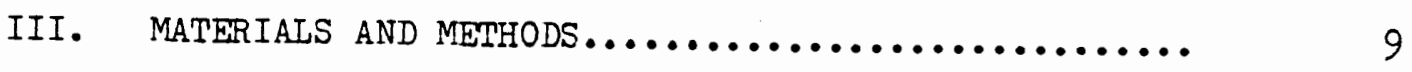

Collection Techniques..................... 9

Culture Techniques....................... 9

Chromosome Techniques..................... 9

Chromosome Staining Techniques............. 10

TV. RESULTS................................ 11

V. DISCUSSION............................. 21

REFERENCES .................................... 26 


\section{IIST OF TABLES}

TABLE

PAGE

I. SITE OF CAPTURE.

II. CHROMOSOME DISTRIBUTION OF C-BANDS................ 


\section{LIST OF FIGURES}

FIGURE

PAGE

1. Standard karyotype of Tursiops truncatus.............

2. Standard karyotype of Tursiops truncatus gilli........

3. C-banded karyotype of Tursiops truncatus.

4. C-banded karyotype of Tursiops truncatus gilli.

5. C-band chromosome variants..................... 
CHAPTER I

INTRODUCTION

There is considerable controversy over the number of existing species in the genus Tursiops (Odontoceti: Delphinidae). Hershkovitz (1966) delineates two species, Tursiops truncatus and T. gilli. Two recognized subspecies of $\mathrm{T}$. truncatus are based on geographical distinctions--T. t. aduncus Ehrenberg 1873, in the Indian Ocean, Mediterranean Sea, South Pacific Ocean and South AtIantic Ocean, and $\underline{T}$. t. truncatus Montagu 1921, in the North Atlantic Ocean. T. gilli Dall 1873, occurs in the North Pacific Ocean. Hershkovitz admits that there may be some overlapping of $\underline{T}$. t. aduncus with $\underline{T}$. gilii off the coast of Baja California and southern Mexico, and urges a taxonomic revision of this genus. Walker (1975) distinguishes an inshore and offshore form of T. gilli off southern California and Baja California which may correlate with Hershkovitz's (1966) overlapping of T. t. aduncus with $\underline{\text { T. gilli. }}$ Walker (1975) identifies two forms of T. gilli based on cranial measurements, feeding habits and behavior but has not documented these distinctions. Mitchell (1975) designates inshore and offshore forms of T. truncatus based on observed size differences but speculates that these may be subspecies of T. truncatus; this could correlate with Hershkovitz's idea that T. t. aduncus of the South Atlantic overlaps with T. t. truncatus of the North Atlantic. Recently the U. S. Marine Mammal Commission (1976) assimilated all species of the genus Tursiops 
truncatus with worldwide distribution. This is in agreement with Rice (1977)

By examining chromosomes to compare variations in structure between closely related species and races, cytogeneticists have documented that certain types of chromosomal rearrangements can create genetic isolating mechanisms leading to speciation (White, 1973).

In an attempt to correlate chromosomal data with possible species delineation, this study investigates the presence of chromosomal variants between the North Atlantic bottlenose dolphin, I. truncatus, and the North Pacific bottlenose dolphin, 里 $\underline{t}$ gilli. Blood samples from the two forms were available from oceanaria in the United States. Location of capture of each animal sampled (Table I) was correlated with karyotype to enable comparison of chromosome morphology with geographic range. 
TABLE I

SITE OF CAPTURE

T. truncatus

023

Mississippi coast ( Gulf of Mexico)

029

Titusville, Fl. (Atlantic Ocean)

031

Titusville, Fl. (Atlantic Ocean)

033

Titusville, Fl. (Atlantic Ocean)

034

Titusville, Fl. (Atlantic Ocean)

035

Titusville, Fl. (Atlantic Ocean)

708

Titusville, Fl. (Atlantic Ocean)

722

Titusville, Fl. (Atlantic Ocean)

801

Titusville, Fl. (Atlantic Ocean)

T. t. gilli

017

San Diego, Ca. (Pacific Coast)

127

Puerto Citos, Mexico (Pacific Coast)

811

Catalina, Ca. (Pacific Ocean)

812

Catalina, Ca. (Pacific Ocean)

813

Catalina, Ca. (Pacific Ocean) 
CHAPTER II

\section{IITERATURE REVIEW}

Heitz (1928) differentiated between darkly-staining portions of the chromosome which remained condensed throughout mitosis and the lighter stained regions which decondensed at the end of mitosis. He called the permanently condensed regions heterochromatin. Brown (1966) recognized two types of heterochromatin---facultative and constitutive. Facultative heterochromatin may contain structural genes (Iittau, et al, 1964), but they are inactivated as in the Barr body of female mammalian cells (Barr and Bertram, 1949; Ohno, et al, 1959, 1961; Ifon, 1967) and the entire paternal haploid set of chromosomes in the male mealy bug, Planococcus citri (Nur, 1966; White, 1973). Constitutive heterochromatin is presumed inactive in transcribing gene products (Hsu, 1962; and Brown, 1966), and is associated with specific regions of the chromosome. It has been found adjacent to the centromere (Ohno, et al, 1959; Swanson, 1957). Ferguson-Smith and Handmaker (1963) found constitutive heterochromatin adjacent to secondary constrictions. Hsu (1963), as well as Hsu and Arrighi (1971) and Arrighi and Hsu (1971), localized constitutive heterochromatin at the telomeres. Lee and Yunis (1971a,b) and Arrighi and Hsu (1971) localized constitutive heterochromatin interstitially within the length of the chromosome.

Pardue and Gall (1970) developed a technique for staining heterochromatin in Mus musculus by treatment of metaphase cells on 
slides with alkali $(0.07 \mathrm{NaOH})$ followed by staining with Giemsa. This procedure was modified by Arrighi and Hsu (1971) and Yunis, et al (1971) for use on human cells, and reveals a characteristic dense staining of constitutive heterochromatin (Comings and Mattochia, 1972). These darkly-staining areas are called C-bands. Comings (1977) showed that Cband heterochromatin is a DNA-nuclear matrix protein complex which is resistant to extraction with the various alkalis used prior to Giemsa staining. This protein complex occurs preferentially in constitutive heterochromatin, possibly because the heterochromatin is more condensed or because the protein complex is more intimately bound to DNA (Comings, 1978).

In many species C-band constitutive heterochromatin is primarily composed of highly repetitious satellite DNA (Yunis, et al, 1971; Schedl, 1971; Jones, 1977; Comings, 1978) although a small portion of constitutive heterochromatin does not contain repetitious DNA (Comings and Mattochia, 1972; Arrighi, et al, 1974). Satellite DNAs are DNAs of different buoyant densities than the main bulk of DNA when separated by high speed gradient ul tracentrifugation (Kit, 1961). They are composed of short, highly repetitive base sequences (Britten and Kohne, 1968) and have been localized to constitutive heterochromatin in Mus musculus (Jones, 1970; Pardue and Gall, 1970), Microtus agrestis (Arrighi, et al, 1970; Lee and Yunis, 1971a,b), Cavia porcellus (Yunis and Yasmineh, 1970), Peromyscus spp. (Pathak, et al, 1973) and humans (Arrighi and Hsu, 1971; Saunders, et al, 1972; Craig-Holmes, et al, 1973; Gosden, et al, 1977). Because of their highly repetitive base sequences, satellite 
DNAs are not believed to code for any gene products, but are considered important in functioning to maintain the structure of the chromosome (Arrighi and Hsu, 1971; White, 1973).

Intraspecific variations in heterochromatin have been documented in the guinea pig, Cavia porcellus (Bianchi and Ayres, 1971; Southern, 1970), the jungle hamster, Phodopus sungorous (Radzhabli, 1977), the North American white footed mouse, Peromyscus boylii (Lee, et al, 1972), the North American deer mouse, Peromyscus maniculatus (Pathak, et al, 1973), the crab-eating macaque, Macaca fasicularis (Dutrillaux, et al, 1979), and humans (Pearson, et al, 1973; Craig-Holmes, et al, 1973; and Sekhon and Sly, 1975). Interspecific comparisons between closely related species of the same genus have revealed close karyotypic agreement by G-banding with great variations in amount and location of C-band heterochromatin (Pathak, et al, 1973; Sasaki, et al, 1975; Craig Holmes, et al, 1973; Radzhabli, 1977; Dutrillaux, et al, 1979). Additional comparisons between related species not of the same genus have revealed similar homologies in G-banding with karyotypic variation attributable exclusively to C-band heterochromatin differences (Stock and Hsu, 1973; Dutrillaux, et al, 1978).

Apparently intraspecific and interspecific variations in C-band heterochromatin are ubiquitous in animal species and therefore are not considered a valid criterion for establishing taxonomic relationships. Stock and Hsu (1973), however, speculated that species polymorphisms, presumably including heteromorphism in heterochromatin, may be valuable in revealing molecular evolution and speciation. They theorized that differences in the karyotype of the African green monkey (Cercopithecus 
aethiops) and the Rhesus macaque (Macaca mulatta) are explained by the deletion of $\mathrm{C}$-band heterochromatin from the $\underline{C}$. aethiops karyotype giving rise to the M. mulatta karyotype.

Although the function of heterochromatin in the genome has not been clearly outlined, Nankivell (1976) and Miklos and Nankivell (1976), observed that in the grasshopper genus Atractomorpha, chiasmata (leading to crossing over between homologous pairs) occur at a maximal distance from heterochromatin present in the chromosome. Thus, there appears to be a suppression of crossing over near heterochromatic regions of the chromosome and an interference with crossing over between homologs (Thomas and Kaltsikes, 1974). This suppression and interference is hypothesized to stabilize the genes adjacent to the heterochromatin and to cause these genes to be transmitted more frequently as a linkage group (Jones, 1977). However, Hansmann (1976) has documented an increased incidence of translocations between chromosomes containing satellite DNA heterochromatin.

It has been proposed that variations in C-bands within a species reflect alterations in the structure and distribution of repetitious DNA (Jones, 1977; Miller, 1977). The rapid expansion of repetitive heterochromatin from changes in small base sequences---"saltatory replication" (Britten and Kohne, 1968)---can occur during the evolution of a given species and perhaps during the lifetime of a given individual (Bianchi and Ayres, 1971).

Mayr (1982) stated that the process of speciation, which is the production of new daughter species (Mayr, 1942), can be traced back to intraspecific variation, starting with minute changes. "Any genetic 
reconstruction of a sexually reproducing population starts with the change of a single chromosome and has to pass through a stage of polymorphism or heterozygosity" (Mayr, 1982).

My study was an investigation of $\mathrm{C}$-band constitutive heterochromatin in two possibly distinct types of bottlenose dolphins of the genus Tursiops, $\underline{T} \cdot \underline{\text { truncatus }}$ and $\underline{T} \cdot \underline{t} \cdot \underline{\text { gilli }}$, to determine the amount of intraspecific variation in heterochromatin, and thus potentially in repetitive DNA which occurs in these animals. Standard karyotypes were established for each group, then C-banding was performed to document constitutive heterochromatin variants in these animals, in an effort to analyze the potential for speciation in these two groups. 


\section{CHAPTER III}

\section{MATERIALS AND METHODS}

Collection Techniques. Blood was obtained by venipuncture of superficial vessels in the fluke of captive T. truncatus and T. t. gilli held at Sea World Florida and Sea World San Diego. Blood was drawn by Sea World employees into heparinized vacutainers and kept refrigerated until cultured.

Culture Techniques. Approximately $1 \mathrm{ml}$ of whole blood was added to culture media consisting of $5 \mathrm{ml}$ RPMI 1640 (Gibco) supplemented with 25\% fetal calf serum (Colorado Serum Company, $25 \mathrm{ml} / 100 \mathrm{ml}$ media), penicillin $(0.04 \mathrm{ml} / 100 \mathrm{ml}$ media $)$, streptomycin $(0.05 \mathrm{ml} / 100 \mathrm{ml}$ media $)$, and phytohemagglutinin (PHA-M, Burroughs-Wellcome reconstituted, $1.8 \mathrm{ml} / 125$ ml supplemented media). Cultures were incubated for four days at $37^{\circ} \mathrm{C}$ in $5 \% \mathrm{CO}_{2}$.

Chromosome Techniques. Colcemid ( $0.05 \mathrm{ml}$ Gibco, $10 \mathrm{meq} / \mathrm{ml})$ was added 21 $1 / 2 \mathrm{hr}$ before harvest, then removed by centrifugation after 1-2 $\mathrm{hr}$. Fresh culture media was added to the cells. Colcemid was added again for 10 min immediately prior to harvest. Metaphase cells were collected by centrifugation, and treated by addition of either of two hypotonic solutions: $0.075 \mathrm{M} \mathrm{KCl}$ for $41 / 2 \mathrm{~min}$; or $1: 1 \mathrm{KCl}$ to $20 \%$ fetal calf serum for 12 min. Cells fixed in the first hypotonic proved better for 
banding; while the latter hypotonic was better for standard staining. Cells were fixed in a $3: 1$ solution of ethyl alcohol and glacial acetic acid for $20 \mathrm{~min}$. Fixative was changed and cells were stored at $0-4^{\circ} \mathrm{C}$.

Chromosome Staining Techniques. SIides from twelve T. truncatus and seven T. t. gilli were examined for metaphase chromosome spreads. Cbanding studies were conducted to delineate polymorphisms. Air-dried and flame-dried slides were prepared from both hypotonic solutions; only air-dried slides were used for C-banding. Slides were stained according to the following techniques:

1. Standard stain---Giemsa (Fisher) 1-50 ml distilled water for $5-7 \min$

2. C-banding---staining of constitutive heterochromatin by immersion of slides in $0.2 \mathrm{~N} \mathrm{HCl}$, treatment with $0.07 \mathrm{~N} \mathrm{NaOH}$ and $2 \times \operatorname{SSC}(0.3 \mathrm{M}$ sodium chloride in $0.03 \mathrm{M}$ trisodium citrate), rinsed in $70 \%$ ethyl alcohol and $95 \%$ ethyl alcohol and incubated in a moist chamber of $2 \times$ SSC at $65^{\circ} \mathrm{C}$ for $12-16 \mathrm{hr}$. Slides were rinsed again in $70 \%$ ethyl alcohol and $95 \%$ ethyl alcohol then stained in a $4 \%$ solution of Giemsa in distilled water at $\mathrm{pH} 6.8$ for $7-10 \mathrm{~min}$.

A minimum of five metaphase cells were examined from each animal with each staining technique. Cells were photographed with a Zeiss camera mounted on an American Optical Series microscope. Kodak S0-115 film was developed with Kodak D-19 developer and prints were made on Kodabromide paper. 
CHAPTER IV

RESULTS

Standard karyotypes were constructed using Giemsa stain. Twelve T. truncatus and seven T. t. gilli were selected for study with banding techniques based on the quality and quantity of metaphase spreads. Nine T. truncatus and five T. t. gilli were successfully C-banded.

In studies by Arnason (1974) and Duffield (1977) the overall homology of the chromosome pairs in T. truncatus and T. t. gilli was established by G-banding. In Tursiops, C-bands appear primarily in chromosomes which can be identified even by standard staining based on centromere position and relative size of the chromosome. By these latter criteria, the 22 chromosome pairs of Tursiops can be arranged for convenience of comparison into four groups of autosomes and the sex chromosomes (Duffield, 1977) (Figures 1 and 2):

Group A: five largest pairs; first two distinctly larger than the other three pairs; distinguishable from each other by relative arm length; third pair intermediate in size; last two pairs shorter and distinguishable from each other by arm length

Group B: five pairs of submetacentric chromosomes; in descending order by size; first two pairs distinctly larger than last three pairs.

Group C: six pairs of metacentric chromosomes; first two to three pairs larger than the last three to four pairs.

Group D: five pairs of acrocentric chromosomes. 

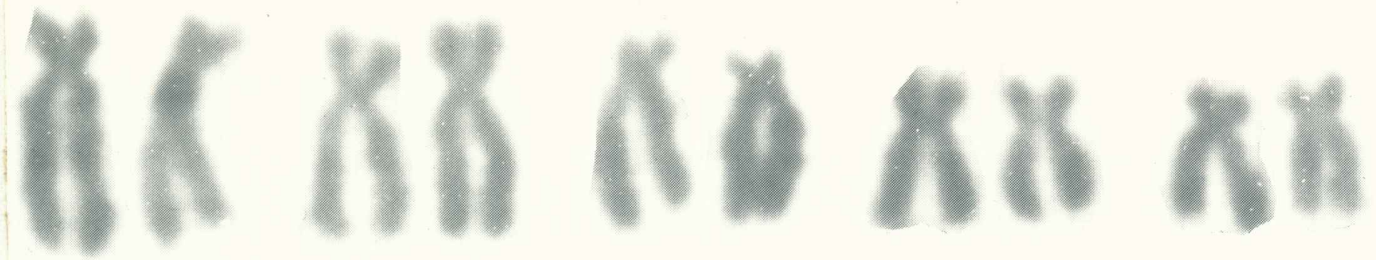

16)

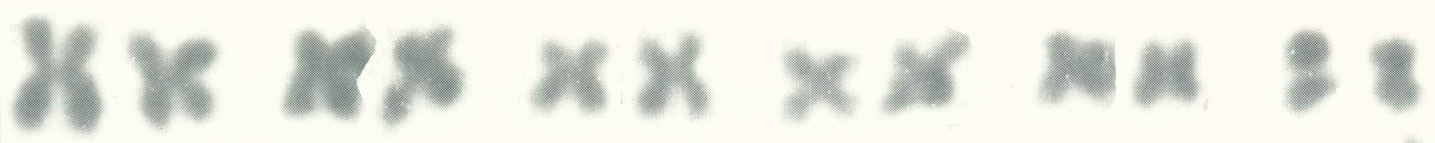

กถทคคกคกคล

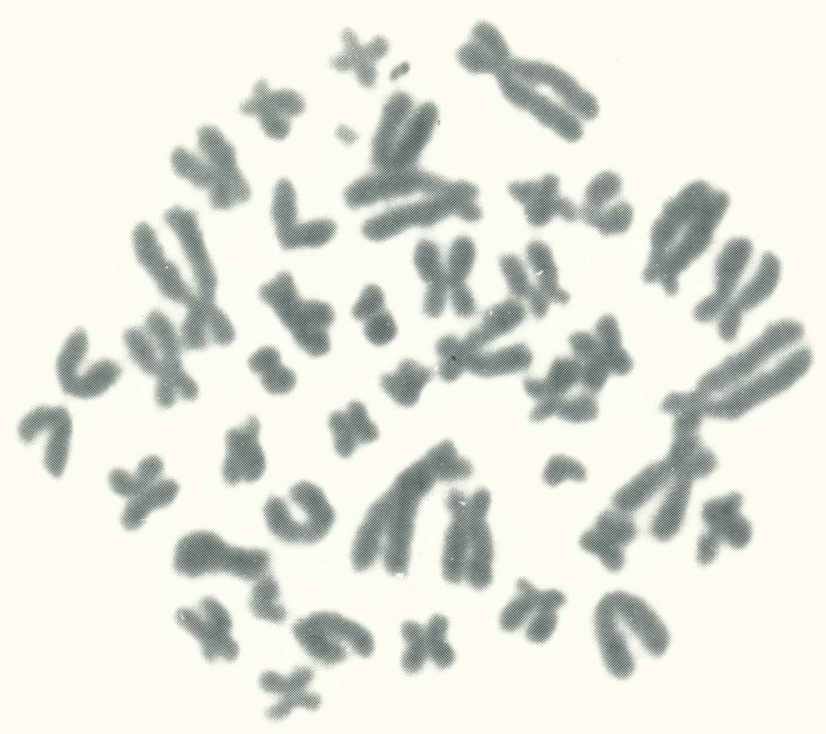

Figure 1. Standard karyotype of Tursiops truncatus. 

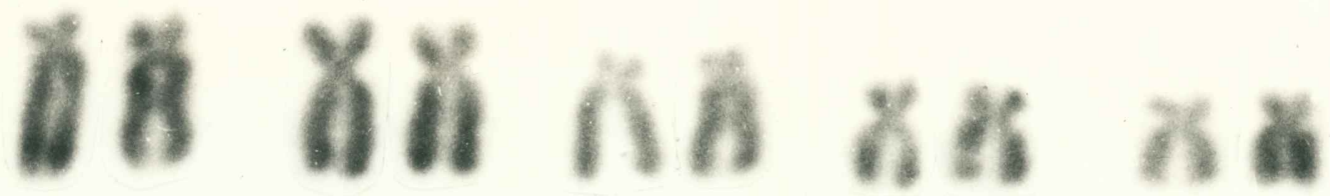

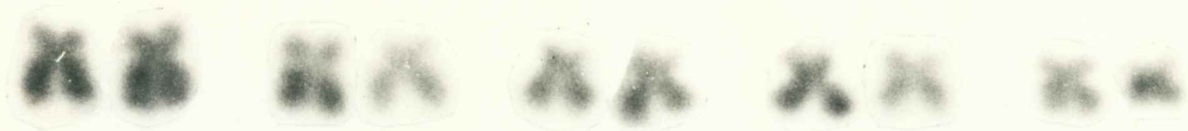

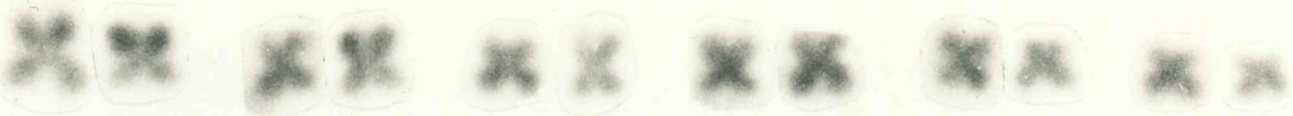

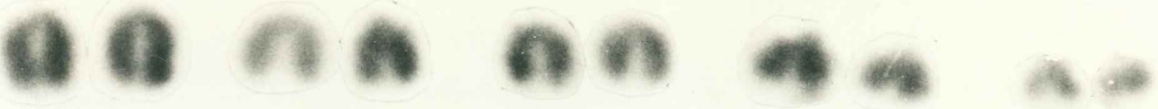

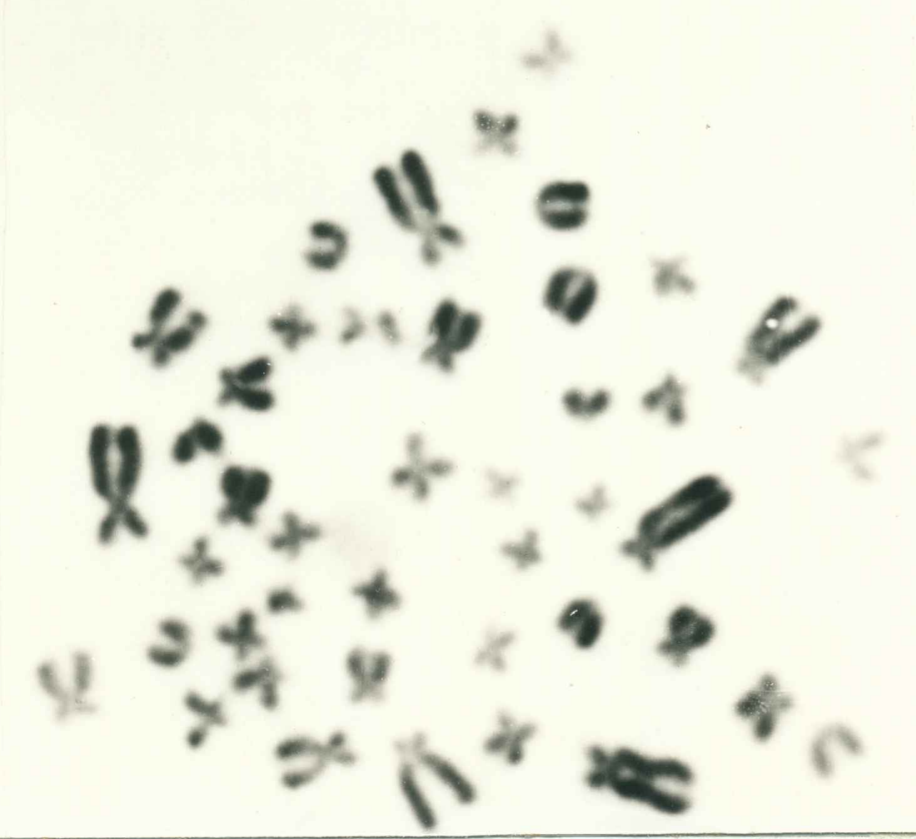

Figure 2. Standard karyotype of Tursiops truncatus gilli. 
Sex Chromosomes: $X$ similar in size to the first two Group B and first Group C chromosome pairs but centromere intermediate in position between submetacentric and metacentric ; $Y$ punctiform.

Group A chromosomes were easily distinguished by their size. The first two Group B chromosome pairs were also easily distinguished by their obvious submetacentric centromere correlated with larger size. The remaining Group B chromosomes were occasionally hard to distinguish with certainty as were the Group C chromosomes. Group D chromosomes were easily distinguished as acrocentrics but could not always be clearly arranged in order of descending size. They were evaluated as a group. The $X$ chromosomes were distinguished by the position of the centromere, while the punctiform $Y$ was clearly distinct.

These animals exhibited interstitial and terminal as well as centromeric C-bands (Figures 3 and 4 ).

All animals had a centromeric and an interstitial $\mathrm{C}$-band on the $\mathrm{q}$ arm of chromosome number one (Figure 5). Seven T. truncatus and two T. t. gilli had a terminal band on the $p$ arm in addition to the other two bands. The other two T. truncatus and three T. t. gilli were heteromorphic for the $p$ terminal band (one homolog of each chromosome pair exhibited the band while the other homolog did not, or had very little terminal band, which was undetectable in these preparations).

All 14 animals had both a $p$ terminal and a $q$ interstitial band on chromosome number two, with no centromeric $\mathrm{C}$-band.

All animals had a $q$ interstitial band on chromosome number three; additionally, four T. truncatus and three $\underline{T}$ t. gilli had a $p$ terminal 

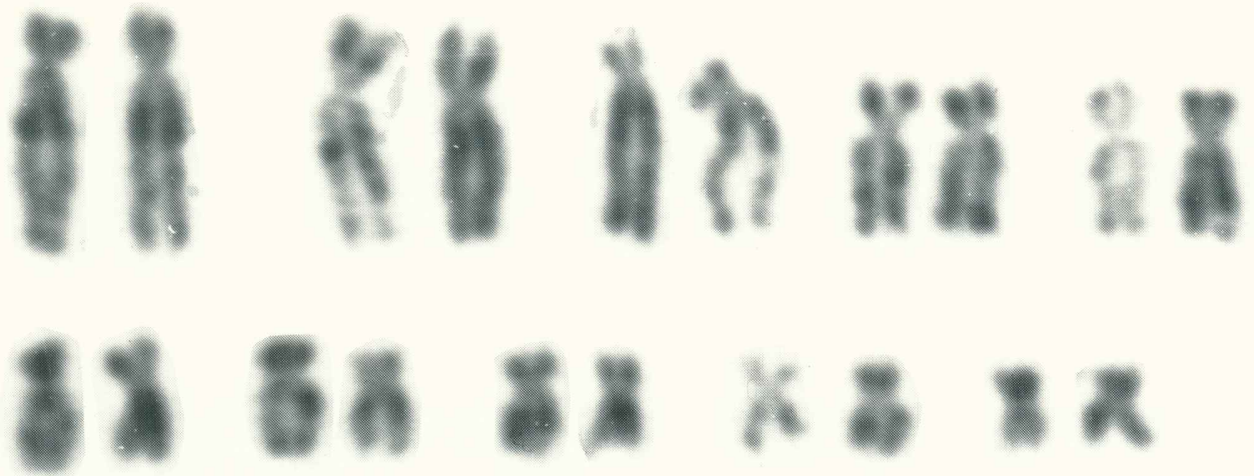

K $\Sigma 2$

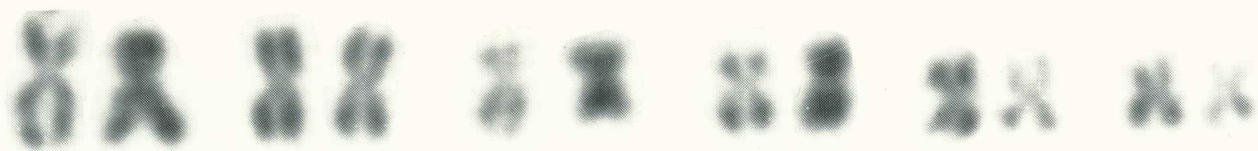

11)
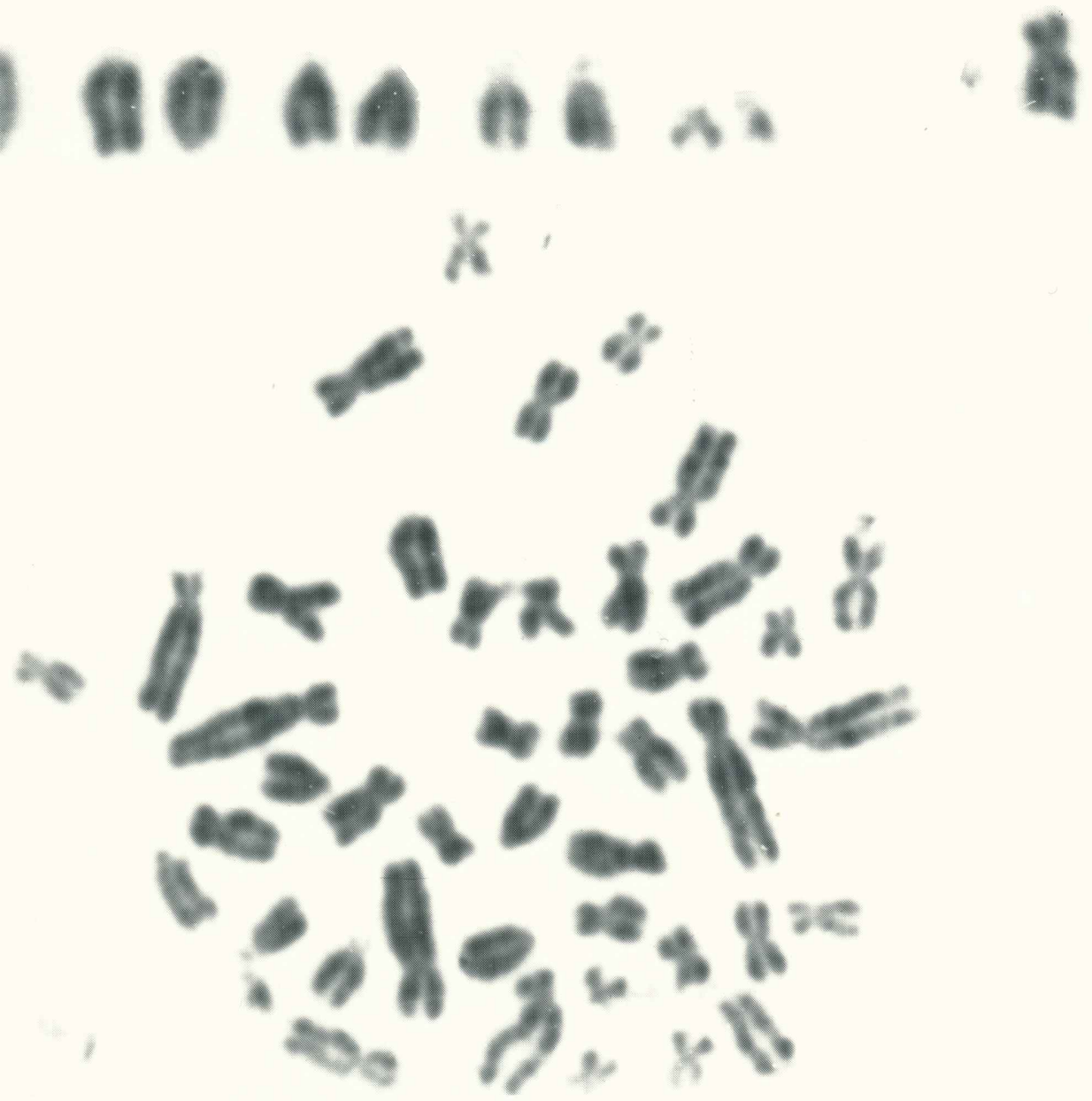

Figure 3. C-banded karyotype of Tursiops truncatus. 


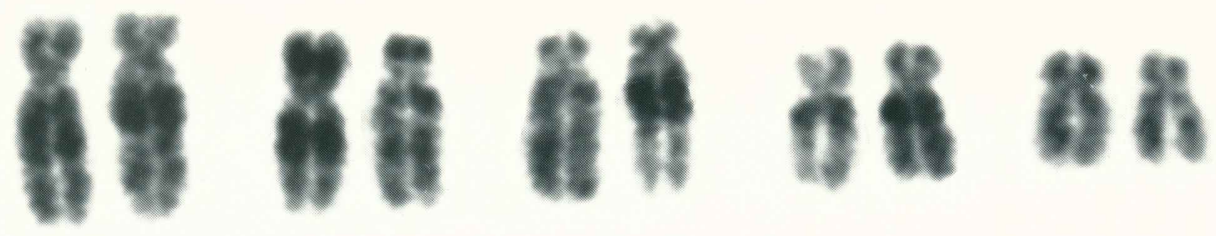

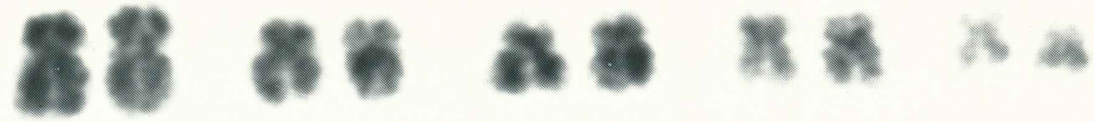

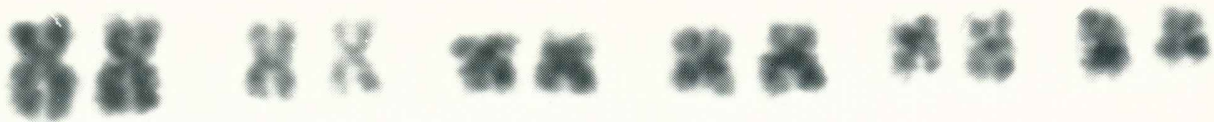

A 4 a
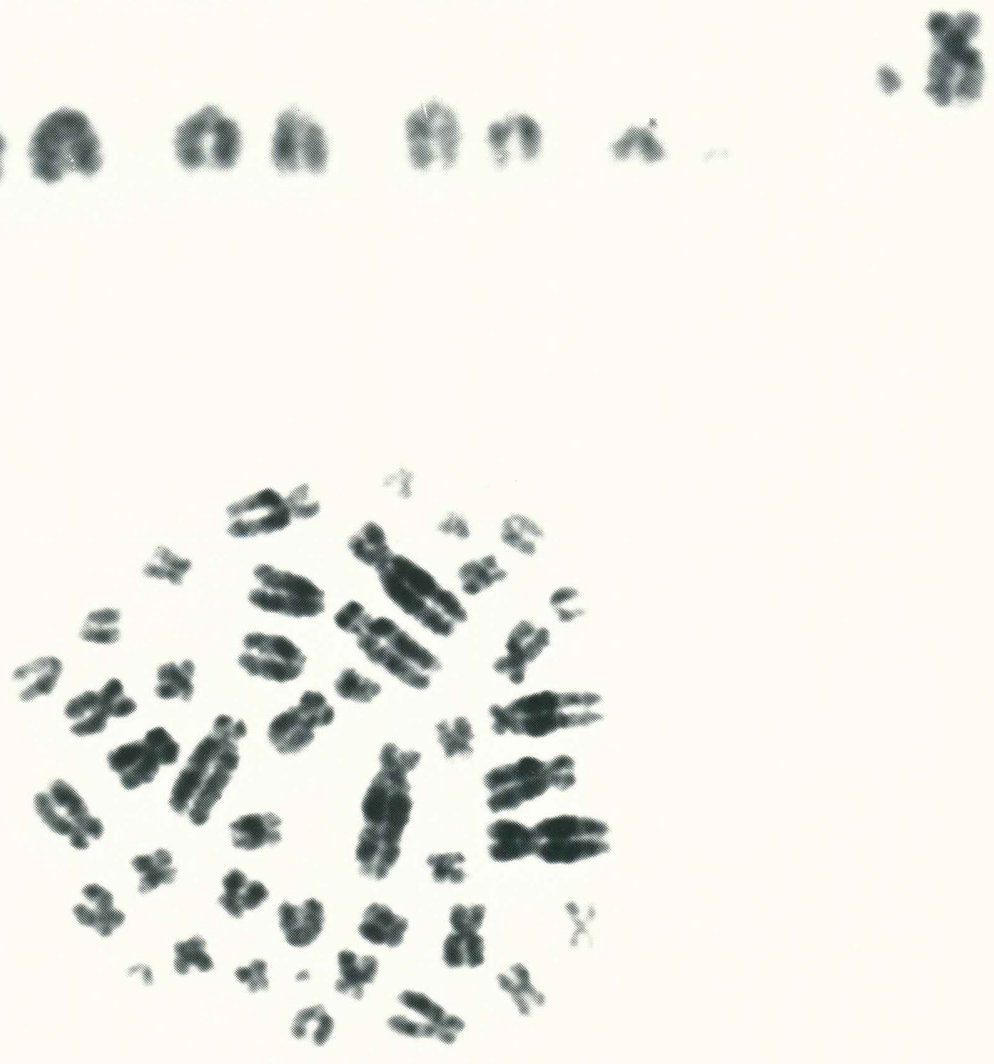

Figure 4. C-banded karyotype of Tursiops truncatus gilli. 
Number 1

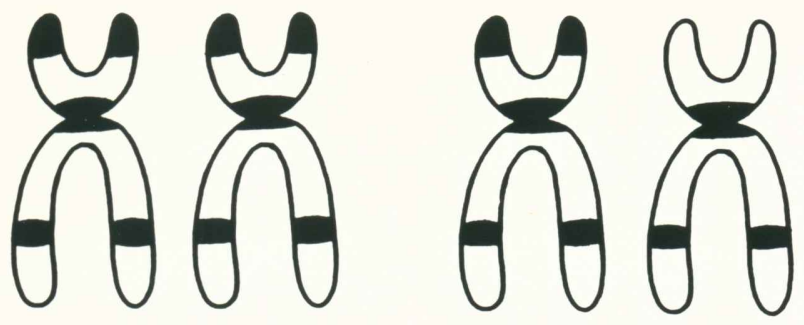

Number 2

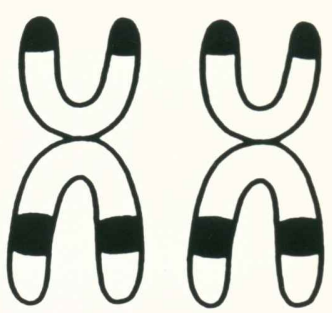

Number 4

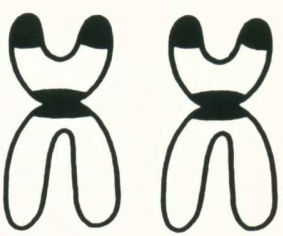

800

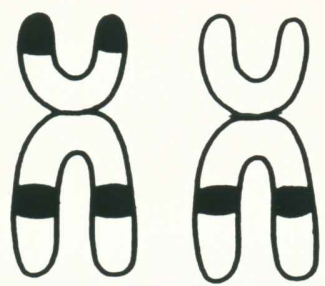

Number 5

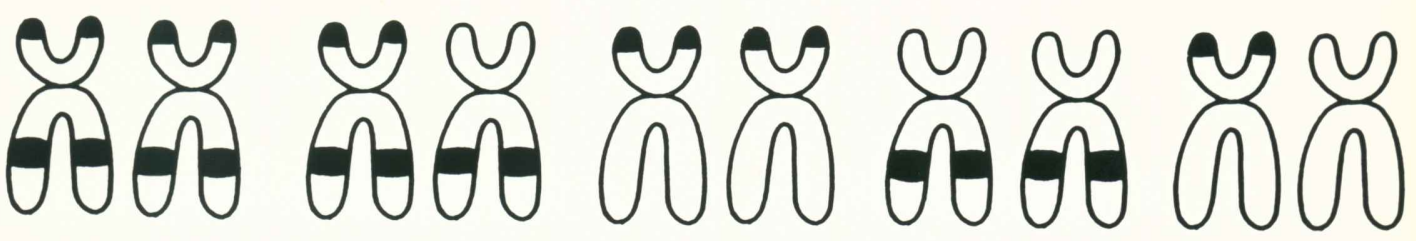

Number 6

(2)
Number 7

तूर
Acros

AOOOOO

Figure 5. C-band chromosome variants. 
band, while the remaining animals were heteromorphic for this band, as with chromosome one.

All animals had a large centromeric $\mathrm{C}$-band and a $\mathrm{p}$ terminal band on chromosome number four.

Chromosome number five exhibited great variability: seven T.

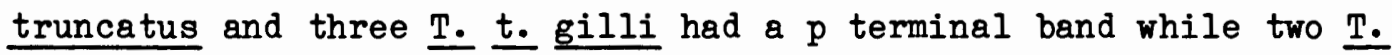

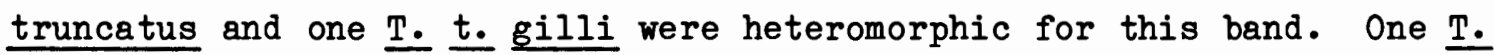
t. gilli had no $p$ terminal band in either homolog. Seven T. truncatus and all five $\underline{T}$ t. gilli had a $q$ interstitial band while the remaining two T. truncatus showed no evidence of a $q$ interstitial band on either homolog.

All animals had both a $p$ terminal and a centromeric $C$-band on chromosome number six.

All animals had a centromeric C-band on chromosome number seven; four T. truncatus and one T. t. gilli also had $p$ terminal $C$-band. Five T. truncatus and three T. t. gilli had no $p$ terminal band on either homolog. Poor visibility in all cells studied made it impossible to determine the presence or absence of this band in one T. t. gilli.

The five acrocentrics were arranged in descending order by size, but due to uncertainty about their exact order, they were evaluated as a group in each animal.

Seven T. truncatus and two T. t. gilli had four acrocentric chromosomes with a centromeric C-band. The other animals, two $\underline{\text { I. }}$ truncatus and three T. t. gilli, had three acrocentrics with a centromeric $\mathrm{C}$-band. 
Two T. truncatus had three acrocentrics with an additional interstitial C-band, while seven T. truncatus and all five T. t. gilli had two acrocentrics with an interstitial C-band in addition to the centromeric band.

Homologs were paired by size and relative centromere position, not by G-band homology. G-banding was attempted in this study but was not successful.

Care was taken during analysis of the heteromorphisms to distinguish dissimilarities owing to population or individual variants and dissimilarities owing to differential condensation of metaphase cells and variable quality of preparation.

There was much C-band variation within Tursiops, and no clear distinctions between the Atlantic and Pacific forms nor between inshore and offshore forms (Table II).

Considering the small sample size, the amount of variation among animals is significant. Only one animal, T. t. gilli 812 , did not exhibit a heteromorphism on any chromosome.

The coastal T. truncatus, 023, displayed more variability than any other animal, followed by coastal T. t. gilli, 017 . The other coastal T. t. gilli, 127, displayed the same amount of variation (1) as the majority of both T. truncatus and T. t. gilli. 
CHROMOSOME DISTRIBUTION OF C-BANDS

\section{Number 1}

q p

inter $\mathrm{p}$
Number 2

q $\quad$ p
Number 3

q p

inter term
Number 4

Number 5
Number $6 \quad$ Number 7
Acros Acros inter term cent term cent term cent cent

$\underline{T}$ truncatus

$\begin{array}{lccccc}023 & \text { X } & \text { hetero } & \text { X } & \text { X } & \text { X } \\ 029 & \text { X } & \text { X } & \text { X } & \text { X } & \text { X } \\ 031 & \text { X } & \text { X } & \text { X } & \text { X } & \text { X } \\ 033 & \text { X } & \text { X } & \text { X } & \text { X } & \text { X } \\ 034 & \text { X } & \text { X } & \text { X } & \text { X } & \text { X } \\ 035 & \text { X } & \text { X } & \text { X } & \text { X } & \text { X } \\ 709 & \text { X } & \text { X } & \text { X } & \text { X } & \text { X } \\ 722 & \text { X } & \text { X } & \text { X } & \text { X } & \text { X } \\ 801 & \text { X } & \text { hetero } & \text { X } & \text { X } & \text { X }\end{array}$

\section{$\underline{T} \cdot \underline{t} \cdot \underline{g i l l i}$}

$\begin{array}{cccccc}017 & \text { X } & \text { hetero } & \text { X } & \text { X } & \text { X } \\ 127 & \text { X } & \text { X } & \text { X } & \text { X } & \text { X } \\ 127 & \text { X } & \text { X } & \text { X } & \text { X } & \text { X } \\ 811 & \text { X } & \text { X } & \text { X } & \text { X } & \text { X } \\ 812 & \text { X hetero } & \text { X } & \text { X } & \text { X } \\ 813 & & & & & \end{array}$

inter---interstitial $\mathrm{C}$-band present

$\begin{array}{cccc}\text { X } & \text { hetero } & \mathrm{X} & \mathrm{X} \\ \mathrm{X} & \text { hetero } & \mathrm{X} & \mathrm{X} \\ \mathrm{X} & \mathrm{X} & \mathrm{X} & \mathrm{X} \\ \mathrm{X} & \text { hetero } & \mathrm{X} & \mathrm{X} \\ \mathrm{X} & \mathrm{X} & \mathrm{X} & \mathrm{X} \\ \mathrm{X} & \text { hetero } & \mathrm{X} & \mathrm{X} \\ \mathrm{X} & \text { hetero } & \mathrm{X} & \mathrm{X} \\ \mathrm{X} & \mathrm{X} & \mathrm{X} & \mathrm{X} \\ \mathrm{X} & \mathrm{X} & \mathrm{X} & \mathrm{X}\end{array}$

absent hetero

$\mathrm{X}$

X absent

absent $X$

X $\quad X$

X X

cent---centromeric $\mathrm{C}$-band present

$\begin{array}{cccc}\mathrm{X} & \text { hetero } & \mathrm{X} & \mathrm{X} \\ \mathrm{X} & \mathrm{X} & \mathrm{X} & \mathrm{X} \\ \mathrm{X} & \text { hetero } & \mathrm{X} & \mathrm{X} \\ \mathrm{X} & \mathrm{X} & \mathrm{X} & \mathrm{X} \\ \mathrm{X} & \mathrm{X} & \mathrm{X} & \mathrm{X}\end{array}$

absent
hetero
X
X

hetero---heteromorphic for $\mathrm{C}$-band absent---absence of $\mathrm{C}$-band
Unable to determine oresence due to poor visibility in all cells examined 
CHAPTER V

DISCUSSION

This study reveals great variation in quantity of C-band heterochromatin in both T. truncatus and T. t. Billi. Walen and Madin (1965) and Duffield, et al (1967) documented a size heteromorphism in the second-largest chromosome pair in their T. truncatus karyotypes which is consistent with my observations in the largest pair. Allowing for the arbitrary assignment of chromosome number to these two pairs, the studies are in agreement and this apparent size heteromorphism is attributable to C-band heterochromatin.

Several size heteromorphisms correlated to C-band constitutive heterochromatin are apparent in the $\underline{T} \cdot \underline{t}$. gilli karyotype presented by Arnason (1974) and in the $\underline{T}$. $\underline{t} \cdot \underline{\text { gilli }}$ and $\underline{T}$. truncatus karyotypes presented by Duffield (1977).

The large amount of variation in heterochromatin within this small sample of Tursiops suggests that these animals may be forming cytological races capable of undergoing speciation. According to stock and Hsu (1973), species polymorphisms including heteromorphisms in heterochromatin may indicate the presence of incipient races leading to speciation. White (1973) stated that cytogenetic evidence seems to suggest that chromosomal rearrangements play a direct causative role in speciation in some groups of animals.

Prior to the development of chromosome banding techniques 
evolutionists argued that animal speciation could only occur allopatrically---i.e., part of a population becomes geographically separated from the main population, acquires reproductive isolation, then evolves independently from the original population to develop into a different species (Mayr, 1963).

Sympatric speciation was formulated as an alternative---that stable polymorphisms can become established within a population not geographically isolated, and these polymorphisms can cause a gradual divergence genetically from the main population until a distinct species is produced (Maynard-Smith, 1966). Stasipatric speciation was theorized by White (1968) as a modification of sympatric speciation. In stasipatric speciation, an isloating mechanism such as a chromosome rearrangement can spread throughout the range of an existing species creating cytological races which are the source of incipient species. White (1973) also suggested that all of the geographical races capable of evolving into distinct species are chromosomal races. Simpson (1967) argued that opportunities for evolution require the existence of genetic variability which can cause genetic combinations to produce new types of individuals that are then subject to natural selection.

Dutrillawx, et al (1979), theorized that the presence of variable heterochromatic segments within a species increases the possibility for a chromosome to undergo change and fulfills the requirement for genetic variability necessary for speciation.

In many populations, chromosomal variation is found to be vast relative to the morphological diversity and genetic distance in these 
populations (Marks, 1983). The present study suggests that the presence of $\mathrm{C}$-band heteromorphisms and polymorphisms within the Tursiops provides the potential for chromosomal variability necessary for speciation.

Arnason (1972) argued that observed karyotypic stability within the Cetacea is due to outbreeding as a result of high mobility in the environment with far-ranging individuals and large breeding groups. For Tursiops, however, there is little evidence that they range over a large area with a great deal of outbreeding. Observations of Tursiops populations under natural conditions suggest that their population structure involves the occupation of distinct home ranges (True, 1891; Caldwell, 1955; Mead, 1975; Wursig and Wursig, 1977) with seasonal migrations due to mating and calving seasons or food fluctuations (Caldwell and Caldwell, 1972; Odell, 1975).

In the Tursiops population observed by Wursig (1978) in the South Pacific, core groups of several adults and one or two calves were seen together consistently in a given home range. Wursig speculated that these small groups may represent breeding populations of related animals, however wursig did observe some far-ranging individuals that may have reproduced between breeding groups. Gunter (1942) also consistently observed small groups of five to ten related animals in the Gulf of Mexico with no observed population fluctuations.

If Tursiops do form breeding units of five to ten related animals with a few far-ranging individuals, then it is possible for these breeding units to become reproductively isolated from each other. 
In the sei whale, Balenopterus borealis, Arnason, et al (1978) observed C-band heteromorphisms and conjectured that this variability could generate genic polymorphisms within a species which would then predispose speciation.

Mayr (1954) analyzed the genetic effects of isolating a small group from the main population and stated that the resulting changes may have the character of a "genetic revolution" leading to speciation. A C-band study in 45 species of hylid frogs of the genus Litoria (King, 1980), documented that these animals had undergone considerable internal karyotypic modification leading to speciation via heterochromatic rearrangements. This is in agreement with Mayr's (1982) observation that any genetic reconstruction has to pass through a stage of heterozygosity or polymorphism.

If a species in the phylogenetic sense is "the largest aggregate of individual organisms that evolve as a unit" wiley (1978), then the breeding units observed in Tursiops may be fulfilling the requirement for speciation by being reproductively isolated and by displaying heterozyøosity in heterochromatin distribution.

On the other hand, if Tursiops populations are composed of breeding units with a few far-ranging individuals which may be outbreeding with other groups, then there may be great variation in C-band heterochromatin between breeding units but not among individuals within a breeding unit.

My study is a preliminary investigation to analyze the presence of variants within different populations of Tursiops. My results indicate that Tursiops populations exhibit a great deal of genetic 
polymorphism as evidenced by C-band heterochromatin variability, which suggests that Tursiops has the potential to form cytological races leading to speciation.

Due to the small sample size in this study and the lack of knowledge about Tursiops population structure, it was not possible to determine if the heterochromatin variability occurs among individual animals or between breeding units. Additional studies of population structure and heterochromatin variability may reveal the existence of cytological races within the Tursiops that are capable of undergoing speciation. 


\section{REFERENCES}

Arnason, U. (1972) "The role of chromosomal rearrangement in mammalian speciation with special reference to Cetacea and Pinnipedia" Hereditas 70:113-118

Arnason, U. (1974) "Comparative chromosome studies in Cetacea" Hereditas $77: 1-36$

Arnason, U, Purdom, I.F. and Jones, K.W. (1978) "Conservation and chromosomal localization of DNA satellites in Balenopterid whales" Chromosome 66:141-159

Arrighi, F.E. and Hsu, T.C. (1971) "Localization of heterochromatin in human chromosomes" Cytogenetics 10:81-86

Arrighi, F.E., Hsu, T.C., Pathak, S. and Sawada, H. (1974) "The sex chromosome of the Chinese hamster; constitutive heterochromatin deficient in repetitive DNA sequences" Cytogen Cell Gen 13:268-274

Arrighi, F.E., Saunders, P. and Saunders, G.F. (1970) "Localization of repetitive DNA in the chromosomes of Microtus agrestis by means of in situ hybridization" Chromosoma (Berl) 32:224-236

Barr, M.C. and Bertram, L.F. (1949) "A morphological distinction between neurons of the male and female and the behavior of the nucleolar satellite during accelerated nucleoprotein synthesis" Nature (London) 163:676-677

Bianchi, N.O. and Ayres, J. (1971) "Polymorphic patterns of heterochromatin distribution in guinea pig chromosomes" Chromosoma (BerI) $34: 254-260$

Britten, R.J., and Kohne, D.E. (1968) "Repeated sequences in DNA" Science 161:529-540

Brown, D.H. and Norris, K.S. (1956) "Observations of captive and wild Cetaceans" J of Mammol 37:311-326

Brown, S.W. (1966) "Heterochromatin" Science 151:417-425

Caldwell, D.K. (1955) "Evidence of home range of an Atlantic bottlenose dolphin" J of Mammol 36(2):304-305

Caldwell, M.C. and Caldwell, D.K. (1972) "Behavior of marine mammals" in Mammals of the Sea ed. by S.H. Ridgway, Thomas, Springfield, Mass.

Caspersson, T., Farber, S., Foley, G.E., Kudynowski, J., Modest, E.J., Simonsson, E., Wazh, V. and Zech, L. (1968) "Chemical

differentiation along metaphase chromosomes" Exp Cell Res 49: 219222 
Chen, T.R. and Ruddle, F.H. (1971) "Karyotype analysis utilizing differentially stained constitutive heterochromatin of human and murine chromosomes" Chromosoma 34:51-72

Comings, D.E. (1977) "Chromosome banding and chromosomal proteins" in Molecular Human Cytogenetics ed. by R.S. Sparkes, Academic Press, New York

Comings, D. E. (1978) "Mechanisms of chromosome banding and implications for chromosome structure" Ann Rev Gen 12:25-46

Comings, D.E., Avelino, E., Okada, T.A. and Wyandt, H.E. (1973) "Mechanisms of C- and G-banding of chromosomes" Exp Cell Res $77: 469-493$

Comings, D.E. and Mattochia, E. (1972) "DNA of mammalian and avian heterochromatin" Exp Cell Res 71:113-131

Craig-Holmes, A.P., Moore, F.B. and Shaw, M.W. (1973) "Polymorphism of Human C-band heterochromatin 1. Frequency of variants" Am J Hum Gen 25:181-192

Dobzhansky, T.H. (1961) Genetics and the Origin of Species Columbia Univ. Press, New York

Donohue, R.P., Bias, W.B., Renwick, J.H. and McKusick, V.A. (1968) "Probable assignment of the Duffy blood group locus to chromosome 1 in man" Proc Nat Acad Sci (USA) 61:949-955

Duffield, D.A. (1977) "Phylokaryotypic evaluation of the Cetacea" Ph. D. Thesis, Univ. of Calif. at Los Angeles

Duffield, D.A., Ridgway, S.H. and Sparkes, R.S. (1967) "Cytogenetic studies of two species of porpoise" Nature 213:189-190

Dutrillaux, B., Biemont, M.C., Viegas-Pequignot, E. and Laurent, C. (1979) "Comparison of the Karyotypes of four Cercopithecoidae: Papio papio, P. Anubis, Macaca mulatta and M. Fasicularis" Ctyogen CeII Gen 23:77-83

Dutrillaux, B., Viegas-Pequignot, E., Dubos, C. and Masse, R. (1978) "Complete or almost complete analogy of chromosome banding between the baboon (Papio papio) and man" Hum Genet 43:37-46

Ferguson-Smith, M.A. and Handmaker, S.D. (1963) "The association of satellited chromosomes with specific chromosomal regions in cultured human somatic cells" Ann Hum Gen 27:143-156

Gosden, J.R., Mitchell, A.R. and Seuanaz, H.N. (1977) "Localization of sequences complementary to human satellite DNA's in man and the 
Hominoid apes" in Molecular Human Cytogenetics ed. by R.S. Sparkes, Academic Press, New York

Gunter, G. (1942)"Contributions to the natural history of the bottlenose dolphin, Tursiops truncatus (Montagu) on the Texas coast, with particular reference to food habits" J Mammol 23(3):267-276

Hansmann, I. (1976) "Structural variability of human chromosome 9 in relation to its evolution" Hum Genet $31: 247$

Harrison, R. J., Boice, R.C. and Brownell, R.L. (1969) "Reproduction in wild and captive dolphins" Nature 222:1143-1147

Heitz, C. (1928) "Das heterochromatin der moose I" Jahrb Wiss Bot 69: $762-818$

Hennig, W. and Walker, P.M.B. (1970) "Variations in the DNA from two rodent families (Cricetidae and Muridae)" Nature 225:915-919

Hershkovitz, P. (1966) "Catalog of living whales" U.S. Nat Mus Bull 246

Hsu, T.C. (1962) "Differential Rate in RNA synthesis between euchromatin and heterochromatin" Exp Cell Res 27:332-334

Hsu, T.C. (1963) "Longitudinal differentiation of chromosomes and the possibility of interstitial telomeres" Exp Cell Res Suppl 9:73-85

Hsu, T.C. and Arrighi, F.E. (1971) "Distribution of constitutive heterochromatin in mammalian chromosomes" Chromosoma (Berl) $34: 243-253$

Jones, K.W. (1970) "Chromosomal and maclear location of mouse satellite DNA in individual cells" Nature (London) 225:1912-1915

Jones, K.W. (1977) "Repetitive DNA and primate evolution" in Molecular Structure of Human Chromosomes ed. by J.J. Yunis, Academic Press, New York

King, Max (1980) "C-banding studies on Australian hylid frogs: Secondary constriction structure and the concept of euchromatin transformation" Chromosoma (Berl) 80:191-217

King, Max (1985) "The Canalization Model of Chromosomal Evolution: A Critique" Syst Zool 34(1)69-75

Kit, S. (1961) "Equilibrium sedimentation in density gradients of DNA preparations from animal tissues" J Mol Biol 3:711-716

Kulu, D.D. (1971) "Evolution and Cytogenetics" in Mammals of the Sea: biology and medicine ed. by S.H. Ridgway, Thomas, Springfield, III. 
Kulu, D.D., Veomett, I. and Sparkes, R.S. (1971) "Cytogenetic comparisons of four species of Cetaceans" J Mammol 152 (4):828-832

Lee, J.C. and Yunis, J.J. (1971a) "A developmental study of constitutive heterochromatin in Microtus agrestis" Chromosoma 32:237-250

Lee, J.C. and Yunis, J.J. (1971b) "Cytological variations in the constitutive heterochromatin of Microtus agrestis" Chromosoma $35: 117-124$

Lee, M.R., Schmidly D.J. and Huheey, C.C. (1972) "Chromosomal variation in certain populations of Peromyscus boylii and its systematic implications" J Mammol 53: 697-707

Lewin, B.L. (1974) Gene Expression Volume 2 John Wiley and Sons, New York

Littau, V.C., Allfrey, V.G., Frenster, J.H. and Mirsky, A.E. (1964) "Active and inactive regions of chromatin as revealed by electron microscope autoradiography" Proc Nat Acad Sci (USA) 52:93-100

Lyon, M.F. (1967) "Sex chromatin and gene action in the mammalian Xchromosome" Amer J Hum Gen 14:135-148

Marks, Jon (1983) "Rates of Karyotype Evolution" Syst Zool 32(2):207-9

Maynard-Smith, J. (1966) "Sympatric speciation" Amer Naturalist 100:637650

Mayr, Ernst (1942) Systematics and the Origin of Species Columbia University Press, New York

Mayr, Enst (1954) "Changes of Genetic Environment and Evolution" in Evolution as a Process ed. by J. Huxley, Allen and Unwin, London

Nayr, Ernst (1963) Animal Species and Evolution Harvard University Press, Cambridge, Mass.

Mayr, Ernst (1982) "Speciation and Macroevolution" Evolution 36(6): $1119-1132$

Mead, J.G. (1975) "Preliminary report on the former net fisheries for Tursiops truncatus in the Western North Atlantic" J Fish Res Bd Can 32:1155-1162

Miklos, G.I.G. and Nankivell, R.N. (1976) "Telomeric satellite DNA functions in regulating recombination" Chromosoma (Berl) 56:143167

Miller, D.A. (1977) "Evolution of primate chromosomes" Science 198:11161124 
Mitchell, E. (1975) "Report of the Committee on Smaller Cetaceans" J Fish Res Bd Can 32(7):889-983

Moore, W.S. (1977) "An evaluation of narrow hybrid zones in vertebrates" Quarterly Rev Biol 52:263-277

Nankivell, R.N. (1976) "Karyotype differences in the crenaticeps group of Atractomorpha (Orthoptera, Acridoidea, Pyrgomorphidae)" Chromosoma (Berl) 56:127-142

Nur, U. (1966) "Nonreplication of heterochromatic chromosomes in a mealy bug, Planococcus citri (Coccoidea: Homoptera)" Chromosoma 19:438439

Odell, D.K. (1975) "Status and aspects of life history of the bottlenose dolphin, Tursiops truncatus, in Florida" J Fish Res Bd Can $32(7): 889-983$

Ohno, S., Kaplan, W.D. and Kinosita, R. (1959) "Formation of the sex chromatin by a single $\mathrm{X}$-chromosome in liver cells of Rattus norvegicus" Exp Cell Res 18-415-418

Ohno, S., Kaplan, W.D., Trujillo, J.M. and Kenosita, R. (1961) Nucleolus-organizers in the causation of chromosomal anomalies in man" Lancet ii: 123-126

Pardue, M.L. and Gall, J.G. (1970) "Chromosomal localization of mouse satellite" DNA Science 168:1356-1358

Pathak, S., Hsu, T.C., and Arrighi, F.E. (1973) "Chromosomes of Peromyscus (Rodentia, Cricetidae) IV: The role of heterochromatin in karyotypic evolution" Cytogen Cell Gen 12:315-326

Pearson, P.L., Geraedts, J.P.M. and Van der Linden, A.G.J.M. (1973) "Constitutive heterochromatin in man" in Symposia Medica Hoechst 6 Modern Aspects of Cytogenetics, ed. by R.A. Pfeiffer, F.K. Schattauer, Verlag, Stuttgart, Germany

Prasad, N., Mumford, D.M., Barsales, P.B., Whitman, T. and Wilbur, J.R. (1970) "Cytogenetic studies of dolphin, Tursiops truncatus, by an extended tissue culture technique" Experentia 26:1167-1168

Radzhabli, S.I. (1977) "C heterochromatin in the evolution of mammalian karyotypes" Dokl Akad Nauk SSR 234(4):935-936

Rice, D.W. (1977) "A list of the marine mammals of the world (Third Edition)" NOAA Technical Report NMFS SSRF-711

Saayman, G.S. and Tayler, C.K. (1973) "Social organization of inshore dolphins (Tursiops aduncus and Sousa) in the Indian Ocean" J Mammol $54(4): 993-996$ 
Sasaki, M., Oshimura, M., Takahashi, E. and Kondo, N. (1975) "A comparative banding analysis of chromosomes in three opecies of Lemurs (Primates, Lemuridae)" Genetica 45:253-261

Saunders, G.F., Hsu, T.C., Simes, E.L. and Arrighi, F.E. (1972) "Locations of a human satellite DNA in human chromosomes" Nature New Biol (London) 236:244-246

Schedl, W. (1971) "An analysis of the human karyotype using a reassociation technique" Chromosoma 34:448-454

Sekhon, G.S. and Sly, W.S. (1975) "Inheritance of Q and C polymorphisms" Am J Hum Gen 27:79A

Sergeant, D.E., Caldwell, D.K. and Caldwell, M.C. (1973) "Age, growth and maturity of bottlenosed dolphin, Tursiops truncatus from northeast Florida" J Fish Res Bd Can 30:100-111

Simpson, G.G. (1961) Principles of Animal Taxonomy Columbia Univ Press, New York

Simpson, G.G. (1967) The Meaning of Evolution Yale Univ Press, New Haven, Conn.

Southern, E.M. (1970) "Base sequence and evolution of Guinea pig satellite DNA" Nature 227:794-798

Stock, A.D. and Hsu, T.C. (1973) "Evolutionary construction in arrangement of genetic material" Chromosoma (Berl) 43:211-224

Straney, D.O. (1978) "Variance partitioning and nongeographic variation" J Mammo1 59:1-5

Swanson, C.P. (1957) Cytology and Cytogenetics Prentice-Hall, Englewood Cliffs, New Jersey

Sumner, A.T. (1972) "A simple technique for demonstrating centromeric heterochromatin" Exp Cell Res 75(1):304-305

Thomas, J.B. and Kaltsikes, P.J. (1974) "A possible effect of heterochromatin on chromosome pairing" Proc Nat Acad Sci (USA) $71: 2787$

True, F.W. (1891) "Observations on the life history of the bottlenose dolphin" U.S. Nat Mus Proc 13:97-203

U.S. Marine Mammal Commission (1976) Marine Mammal Names Used by the Marine Mammal Commission, Washington, D.C.

Walen, K.H. and Madin, S.H. (1965) "Comparative chromosome analysis of the bottlenose dolphin (Tursiops truncatus) and the pilot whale 
(Globicephala scamonii)" Amer Nat 99:349-354

Walker, W.A. (1975) "Review of the live-capture fishery for smaller cetaceans taken in Southern California waters for public display, 1966-1973" J Fish Res Bd Can 32(7):1197-1221

Wang, H.C. and Federoff, S. (1972) "Banding in human chromosomes treated with trypsin" Nature New Biol 235:52-53

White, M.J.D. (1968) "Models of speciation" Science 159:1065-1070

White, M.J.D. (1973) Animal Cytology and Evolution Cambridge Univ Press, New York

Wiley, E.0. (1978) "The evolutionary species concept reconsidered" Syst Zool $27: 17-26$

Wursig, B. (1978) "Occurrence and group organization of Atlantic bottlenose porpoises (Tursiops truncatus) in an Argentine Bay" Biol Bull 154:348-359

Wursig, B. and Wursig, M. (1977) "The photographic determination of group size, composition and stability of coastal porpoises (Tursiops truncatus)" Science 198:755-756

Yablokov, A.V. (1965) "Convergence or Parallelism in the Evolution of Cetaceans" Int Geol Rev 7:461-68

Yunis, J.J., Roldan, L., Yasmineh, W.G. and Lee, J.C. (1971) "Staining of satellite DNA in metaphase chromosomes" Nature (London) $231: 532-533$

Yunis, J.J. and Yasmineh, W.G. (1970) "Satellite DNA in constitutive heterochromatin of the guinea pig" Science 168:263-265 